Quest Journals

Journal of Research in Humanities and Social Science

Volume 5 Issue 2 (2017) pp: 70-77

ISSN(Online) : 2321-9467

www.questjournals.org

Research Paper

\title{
The conflicting behavior of the government institutions in the arrangement of local income and budget expenditures
}

\author{
A. Jamaluddin \\ High School of Social and Political Sciences (STISIP) Muhammadiyah Sinjai, South Sulawesi
}

Received 18 Feb. 2017; Accepted 03 Mar. 2017 (C) The author(s) 2017. Published with open access at www.questjournals.org

\begin{abstract}
This study aims to explain the behavior of the conflict between the executive and legislative institution at the stage of preparation of Public Policy Budget (KUA), the stage of preparation of Priorities and Budget Ceiling While (PPAS) and the stage of discussion of the Draft Budget and Expenditure (budgets) Government as well as to analyze models of conflict resolution between the executive and the legislature in the arrangement of local income and budget expenditures (RAPBD) Government. Informants namely the executive, in this case the Local Government and legislature are members of the Assembly of Regency or Municipality (DPRD). The general inductive approach was used to analyze the qualitative data through data reduction, presentation and verification. The study found that there was disagreement and debate between the executive and the legislature that cause conflict behavior in determining the theme of development, development priorities, plans macroeconomic targets and strategies to achieve revenue, financing and expenditures at the stage of preparation of KUA Government. There is disagreement in the determination of the Own-Source Revenue plan $(P A D)$, determination of financing, income and expenditure, the determination of regional government affairs, prioritization of programs and activities and the determination of employee expenses, interest, grants, social assistance and expenditure unexpected cause behavioral conflict between the executive and legislative determination PPAS Government. There is a debate that raises conflict behavior between the executive and legislature in the Plenary Session, Joint Meeting, RAPBD Evaluation Meeting, the Plenary Session of Approval and Evaluation Meeting of Governors discussed the draft budget of the Government.
\end{abstract}

Keywords - Behavior, budgeting, conflict, executive, legislative

\section{INTRODUCTION}

The Division of powers in the implementation of the state government is one of the characteristics of a democracy; there are a variety of power such as organizing body, the legislature, executive, judiciary and others. Generally, countries that implement power-sharing system refer to the trias politica. Trias politica assume state power consists of three kinds of power: first, the legislative authority or the rule making functions; second, the executive power or the power to implement laws (rule application functions); and third, the judiciary or the prosecuting authority for violations of the law (rule adjudication functions). Trias Politica is a normative principle that the powers should not be submitted to the same person in order to prevent abuse of power by those in power. Implementation of government policy in the region, conflicts between the two institutions, namely the executive and legislative branches. Conflict in essence is a reality that occurs as a result of differences or disputes that cannot be avoided and often is creative to justify the interests and objectives, which are not all in line with it.

Conflicts will likely always exist, because the dynamics of the institution or organization is always there. Conflict can lead to the development and progress of the institution or organization or local government could lead to imbalances and failures. Conflicts positive leads tend to deliver such government institution or organization in achieving its goals and conflicts likely to cause a negative lead institution or organization resign. Therefore we need an understanding of all the elements that exist within government institutions or organizations to avoid a conflict that leads to negative.

Law of the Republic of Indonesia Number 23/2014 on Regional Government that the Regional Head executive and the Parliament (legislature) is organizing in local government affairs. The relationship between the executive and the legislature should be an employment relationship or a relationship that is equal in status 
and nature of partnership. An equal footing significantly between executive and legislative branches they have the same position and aligned, meaning not supervise each other. This relationship can be reflected in policymaking and local regulations. Partnerships means that between the executive and the legislature is equally partners in regional policy making to implement regional autonomy in accordance with their respective functions, so between the two institutions can build a relationship or relationships of mutual support (synergy) is not an opponent or competitors with each other in carrying out their respective functions.

The potential conflict between the executive and legislative occurs because the factor the difference of interests between the two sides, especially in the preparation and approval of the draft local income and budget expenditures. Planning and budgeting are part of the decision-making process in governance and development. This is consistent with the mandate of Law the Republic of Indonesia Number 25 Year 2004 on National Development Planning System (SPPN) is guided by an element of the state and society at the level of central government or local governments. One community participation in development implemented through development planning meetings that will generate Regional Long Term Development Plan (RPJPD), Medium Term Development Plan (RPJMD), as well as the Development Plan (RKPD). In order to carry out development in the area of sustainable and continuous manner, each region should have a comprehensive planning system, as outlined in regional planning documents that become reference and guidance in the development process in the region.

Based on the law the Republic of Indonesia number 17/2003 on State Finance and the law number 25/2004 on National Development Planning System and the law number 23/2014 on Regional Government, an area must have a plan consisting of: first, the development plan 20 (twenty) annual or Long Term Development Plan Area (RPJPD). Second, the development plan of 5 (five) years or Medium Term Development Plan (RPJMD) and the third, short-term development plans or 1 (one) year or Local Government Work Plan (RKPD). Development Plan (RKPD) is a document annual planning drafted in order to ensure consistency and synchronization between planning, budgeting, implementation and monitoring, as well as an integral part in the stage of preparation of the Draft Budget and Expenditure (budgets) consisting of the work plan Local Government (RKPD), Public Policy budget (KUA), Priorities and Budget Ceiling While (PPAS) work plan and Budget (RKA) work Unit (SKPD), which is essentially an elaboration of the Medium Term Development plan Area (RPJMD).

Development vision and mission outlined in the Development Plan (RKPD) in the form of annual plans and programs as well as bridging the planning and budgeting process. In addition, as well as to meet local obligations mandated by Law Number 23/2014 on Regional Government. In Article 1 point 32 Regulation of the Indonesian Minister of Home Affairs Number 13/ 2006 regarding Guidelines for Financial Management as amended two times by Regulation of the Minister of Home Affairs Number 21/2011 regarding the Second Amendment to the Regulation of the Minister of Home Affairs Number 13/2006 regarding Guidelines for Financial Management and Article 1 point 25 Regional Regulation Number 3/2009 on the Fundamentals of Financial Management stated that the priorities and Provisional budget Ceiling (PPAS) is a program design priorities and the benchmark limit on the budget given to SKPD for each program as a reference in preparing the budget plan Regional Work Units (RKA-SKPD) as agreed by parliament. Determination of the maximum limit is done after taking into account the personnel expenditure.

Furthermore, the Minister Regulation No. 27/2013 on Guidelines for Budgetary Revenues and Expenditures for Fiscal Year 2014 confirmed that the substance of the Priorities and Budget Ceiling While (PPAS) reflecting regional development priorities associated with the objectives to be achieved, including the priority program of Unit Work (SKPD) related. Priority programs of each Work Unit (SKPD) districts / cities other than adapted to the regional government affairs are handled and has been synchronized with the priorities of national programs that are listed in the Government Work Plan (RKP) in 2015 have also been synchronized with program priorities provinces contained in the Government Work Plan (RKPD) province Year 2015 Priorities and budget ceiling while (PPAS) in addition to describing the budget cap (budget ceilings) while for personnel expenditure, interest, subsidies, grants, social assistance, shopping for the results, financial aid and unexpected expenditures and financing, also describes the budget cap (budget ceilings) while in their respective work units (SKPD) based on priority programs and activities in the Government Work Plan (RKPD). The temporary ceiling will be definitive after the draft local regulations on the budget agreed upon between the head area with the parliament and a draft Regional Regulation on the budget is set by the regional head into Regional Regulation on APBD.

Priority setting includes not only the decision of what is important to do, but also determine the scale of the programs or activities that must be done in advance of the program and other activities based on an understanding of the situation that underlies the need to set these priorities, scheme or design of various alternatives which can be implemented, identify the consequences of each alternative will be selected and decision-making best course of action to be performed. Furthermore, in accordance with the mandate of Article 86 of the Regulation of the Minister of Home Affairs No. 21/ 2011, the draft prepared by the Fiscal Year PPAS 
The conflicting behavior of the government institutions in the arrangement of local income and...

Determining the stage of regional development priorities; Set priorities for each program that is synchronized with the business priorities and national programs listed in the Government Work Plan annually; and draw up the provisional budget ceiling for each program/activity.

The high optimism in the government plan and budget for regional development is not accompanied by good performance and earnest. This can be seen in the Regional Funding Revenue originating from the remaining budget (SiLPA) Fiscal Year previously listed. The condition is not optimal showed regional government in implementing development programs that have been planned, so that the budget is not realized to the fullest. The high income areas and optimism in the preparation of high-spending areas is not accompanied by the realization of government work, and so cannot take advantage of local finance to realize development and improve people's welfare. When viewed from the financial management balanced between revenue and expenditure will lead to friction between the interests of the executive as the executor of the budget and the legislature as a budget watchdog. Friction interests of the executive and legislative potential for conflict in execution of duties and authority of each. Executive and legislative institutions, a government agency that two normatively understood to have differences in their respective institutions, which reflects government executive agencies and legislative institutions that reflect the community as a representative institution. Executive agency in this case is that local governments are responsible include the authority in all aspects of government except foreign affairs, defense and security, justice, monetary, fiscal, and religion. Areas of government in question is concerning the obligation of local governments covering public works, health, education, culture, agriculture, transportation, industry and trade, environment and government policy and all of it was planned and budgeted in the preparation of the Draft Budget Revenue and Expenditure (RAPBD).

Addressing conflicts of interest between the legislature and the executive in the budget process are relevant to the theory of conflict behavior of two dimensions of Robbins (2008) that the conduct of the conflict can be dealt with through action cooperativeness' is a certain level where one party seeks to satisfy the interests of the other party and firmness that is to some degree where a party seeks to meet its own interests. It identified five dimensions of conflict behavior which competitive (assertive and uncooperative), collaborative (assertive and cooperative), avoiding (unassertive and uncooperative), accomodating (cooperative and indecisive) and compromising (the middle in terms of firmness and cooperative).

Problem behaviors agency conflicts raised in this study relates to the preparation of policies and Determination of Regional Budget (APBD) which is implemented by the executive government (Local Government) and the legislature (DPRD). Potential conflicts of this happened because of the behavior and actions of each of the different agencies in actualizing the policy formulation of Public Policy budget (KUA), the preparation of Priorities and Budget Ceiling While (PPAS) and Preparation of Draft Budget (budgets), which refers to government regulation Number 58/2005 on Regional Financial Management Guidelines. This policy is the basis for local governments and the Regional Representatives Council (DPRD) to realize the implementation of financial management accountable and transparent. Budgeting initially by deliberations Development Planning (musrenbang) started in the village, district and county. Musrenbang is the basis for the preparation of Local Government Work Plan (RKPD) in one fiscal year. Local Government Work Plan (RKPD) is the basis for the drafting of the Budget and Expenditure (RAPBD).

Musrenbang is also a public aspirations net more often known as netting romance. Nets romance is a container used to screen a variety of Parliament or the public interests of their constituents. Various interests are accommodated and discussed through the agency budget. Musrenbang implemented by executive referred to in the discussion of budget by budget team. Romance nets carried out by Parliament and then synchronized with Musrenbang. This could potentially occur in synchronization conflicts of interest that led to delays in the preparation and approval of the budget. Understanding the foregoing, it becomes a consideration to see the problem of the conflict is really going on with the Local Government Legislative Council, particularly regarding Budgeting. For this reason researchers interested in studying behavior conflicts with the title in the Local Government Institutions (Studies Executive Institute case with the Legislature in Budgetary Revenue and Expenditure).

Problems studies reviewed in this case the conflict behavior of local government agencies. Conflicts were observed in the executive and legislative bodies of local government. The tendency of the conflict moves through the process and stages shows that the conflict is dynamic. A number of factors led to the dynamics of conflict, such as: the source of structural conflict, a source of conflict role and conduct of the conflict, in which the variation of the dynamics of the conflict can be understood through the intensity of policy conflicts within the organization (Suratman, 2006: 8). The conflict is the dynamic of the organization that developed and evolving all bring change organizational progress (Tyson and Jackson, 2001: 61).

Conflict organizational policy is an attempt to promote the organization. Typically in the organization, conflict is functional and dysfunctional, depending on the construction of a conflict, the interests and goals of the organization. Conflict functional is a conflict that supports the policy goals of the organization, while the conflict is dysfunctional caused the failure of achievement of organizational goals (Tunner, 2000: 36). 
The conflicting behavior of the government institutions in the arrangement of local income and...

Considering the importance of conflict behavior involving party executives with legislature in budgeting becomes important things to consider conflicts that occur because of differences in the interaction of the behavior of the main tasks and functions that often lead to a fight, clash, conflict of interests, opinions, objectives, struggles mental and spiritual suffering (a fight, a collision, a struggle, a contest, opposition of interests, opinions or purposes, mental Strife and agony), which causes conflict behavior is static not dynamic.

Therefore there needs to be a dynamic conflict in accordance with the resolution of the conflict can be managed properly to be innovation for the conduct of the conflict in accordance with the existence in understanding the dimensions of conflict management to achieve organizational effectiveness. Problem statement of this research is the conflict behavior of the executive and legislature in the preparation of the budget for Fiscal Year 2015. This research problems: (1) How does the behavior of the conflict between the executive and legislative institution at the stage of preparation of the Budget of Public Policy (KUA)?, (2) How does the behavior of the conflict between the executive and legislative institution at the stage of preparation of Priorities and Budget Ceiling While (PPAS) Government, (3) How does the behavior of the conflict between the executive and the legislature at the stage of discussion of the Draft Budget and Expenditure (RAPBD) Government?, and (4) How to model the resolution of conflicts between the executive and the legislature in the Regional Budget (APBD) Government?

\section{LITERATURE REVIEW}

The conflict comes from the Latin verb configere meaning hit each other. Sociologically, the conflict is defined as a social process between two people or more (you can also group) in which one of the parties trying to get rid of the other party to destroy it or make it powerless. The administration of conflict means different views and interests of some rules and regulations that differ from the original agreement evidenced in writing (Luthans, 2005). Conflict can be felt, known, expressed through behaviors of communication (Pruitt and Jeffrey, 2004). Conflict is always centered on a few main reasons: the goals, the allocation of shared resources, decisions, and behavior of each of the parties involved (Munandar, 2007).

Conflict is motivated by differences in the characteristics that brought the individual in an interaction. The difference is a source of conflict among them is related to physical characteristics, intelligence, knowledge, customs, beliefs, and so forth. Brought with him the characteristics of the individual in social interaction, conflict is a normal situation in any society and any society is not one who has never experienced a conflict between its members or with other community groups, the conflict will only disappear with the loss of society itself. Conflict and integration runs as a cycle in the community. Controlled conflict will result integration. Instead, an imperfect integration can create conflicts. The conflict can be divided into four kinds, namely the conflict between or in the social role (intrapersonal), for example between the roles in the family or profession, the conflict between social groups (inter-family, inter-gang), conflict organized group and disorganized (police against the mass), and the conflict between national units (campaign, civil war) (Kusnadi, 2003).

Conflict can be a dispute (disagreement), suspense (the presence of tension), or the emergence of other difficulties between two or more parties. Conflicts often cause opposition between the two sides, to the stage where the parties involved looking at each other as a hindrance and nuisance achievement of the needs and objectives of each. There are two definitions of the conflict: first, Substantive conflicts are disputes relating to the group's goals, the allocation of resources within an organization, distribution policies and procedures, and the distribution of job titles, and second, emotional conflicts occur due to any feelings of anger, disbelief, not sympathy, fear and denial, as well as their opposition interpersonal. Conflicts that arise in a work environment can be divided into four levels: first, the conflict within the individual itself. Conflicts can arise in a person in case of overload, in which a person burdened with the responsibility too much work, and can also occur when confronted to a point where decisions must be made involves choosing the best alternative.

Perspective below identifies four episodes of the conflict, namely: (1) approaches conflict, a situation where one has to choose one among several alternatives that are just as good; (2) avoidances conflict, a state in which a person forced to choose one among several alternative destinations which are just as bad; (3) approach - avoidance conflict, a situation where a person motivated by a strong desire to achieve one goal, but on the other hand simultaneously often hindered from that purpose by aspects of unprofitable that cannot be separated from the process of reaching that goal itself, and (4) multiple approach-avoidance conflict, a situation where someone forced confronted with the case of a dual combination of approach-avoidance conflict (Tosi et al., 2006: 1) Conflict interpersonal is a conflict between an individual with individual other. Interpersonal conflict can take the form substantive and emotional, even a major case of conflict faced by managers in terms of interpersonal relationships as part of the managerial duties itself. Intergroup conflict is familiar to any organization, and the conflict led to the difficulty of coordination and integration of activities related to the tasks and jobs. In any case, intergroup relations should be managed as best as possible to maintain collaboration and avoid all the dysfunctional consequences of any conflicts that may arise. 
Interorganizational conflict often associated with competition arising between stakeholder organizations. Interorganizational conflict actually related to the larger issue anymore, for example, disputes between the executive and legislature in the interests of each. In any case, the potential for conflict involves an individual who represents the organization as a whole, not just the internal subunit or group. An unavoidable conflict of bureaucratic organization, because there is always required even by a dynamic organization as happens in local government agencies as an executive with the agency's Representative Council (DPRD) as the legislature in drafting the Regional Budget (APBD). Various disagreements, initiatives, goals and interests between the executive and the legislature are complex and have many organizational units involved often drove the conflict is both conflicts.

Conflicts tend to move through the process or specific stages towards difference and do not follow the pattern of straight, often lead to conflict, so that conflicts tend not static but dynamic. Conflict does not just happen, but there are differences of opinion, initiatives, goals and interests lead to conflicts less innovative behavior that impact on organizational performance and organization less competitive declining or stagnant. Trigger of conflict is associated with structural conflict, conflict of roles and conflict behavior is shown between the executive and legislative branches in the budget. In the real dynamics of conflict is largely determined by the conduct of the conflict. Referenced conflict behavior of two-dimensional model of conflict behavior (Robbins, 2010) makes clear that a conflict behavior measured by the levels of effort to obtain benefits for themselves and give benefits to other parties. These two dimensions will generate handling two-dimensional model the behavior of avoiding conflict, accommodating, and compromising), collaborating and competitive.

Variations interaction organizational behavior rooted from the structure, role conflict and conflict behavior can be understood through the intensity of the conflict. For the executive and legislative branches, the intensity of the conflict is at a continuous ranging from no conflict until the conflict annihilation, where the characteristics ranging from the behavior of disagreement or misunderstanding small move to the behavior of the statement or the difference, then the behavior of verbal attacks were firm, threats, ultimatums, aggressive physical attack to the behavior of a blatant attempt to drop another party. The intensity of the conflict could be lower or higher depending on the resolution of the conflict is the conflict resolution applied either destructive or dysfunctional. Conflicts such as these impede or hinder the performance of the organization if they do not produce innovation constructive conflict behavior (functional) to support the organization's handling of the conflict dimension. Dysfunctional conflict should be avoided and always adaptive to changes in the direction of conflict oriented to the achievement of organizational effectiveness. Organizational effectiveness in resolving the conflict based on the dimension of conflict resolution in the form of avoiding, accommodating, compromising, competing and collaborating (Robbins, 2010).

\section{METHOD}

This research uses a qualitative research approach is comprehensive study was to explore and compare the data thoroughly in accordance with the substance of the focus of the study observed. Qualitative research is research to provide clarification or information on the findings that can be justified as the proposition that became the forerunner of the theory. An informant in this study is the head of the Regional Work Units (SKPD) as the Executive, members of parliament as the legislature, the non-governmental organizations (NGOs) and Community Leaders. The uses of the instrument in qualitative research always refer to an instrument that indicates the capacity of individual researchers. Therefore, it is to be instrumental in this research is the researcher's own (human instrument). As the main instrument, the researcher must override the various matters relating to forms of prejudice, prejudice and assumptions derived from research participants or informants. In order to process data collection, there are three activities carried out by researchers is getting in, getting along and logging the data is in the form of in-depth interviews, observation and documentation. Data analysis techniques used in this study includes a series of data handling activities starting from the stage of collecting data and then analyzed the data according to the stages of data reduction and data presentation, data verification and data reduction.

\section{DISCUSSION AND ANALYSIS}

Conduct conflict the executive and the legislature in budgeting in view of such behavior on the stage of public policy making budgets, prioritization and budget ceilings while the government, discussion of the draft budget of income and expenditure and models of conflict resolution are applied. Problems budgeting is often characterized by differing views, opinions, assumptions, aspirations and interests that led to frequent different views and interests of a rule of different provisions of the original agreement which proved orally and in writing as experienced in the conflict of the executive and legislative branches. Symptoms of conflict can be felt, known, expressed and manifested through the behavior of individuals, groups and organizations to make a difference between the behavior of the other behaviors (Pruitt and Jeffrey, 2004). 
Conflicts involving the behavior of individuals, between individuals, groups and organizations, usually motivated by differences in characteristics that can be categorized in four forms are the conflict between private, sectarian conflict, a conflict between organized groups and groups between units of work, which cause differences in understanding the budget. According Kusnadi (2009) may be a conflict of disputes (disagreement), suspense (the presence of tension) or other difficulties emergence of two or more parties that cause the nature of the opposition in dealing with a topic of study. The existence of a conflict cannot be separated from the goals and needs that led to a difference in the attitude of behavior in dealing with the problem. In principle basically a conflict occurs due consideration of the substantive conflict and emotional conflict. Symptoms of conflict can be defined in two ways, namely substantive conflict and emotional conflict. Substantive conflict is a dispute relating to the group's goals, the allocation of resources of an organization, distribution wisdom, procedures and division of labor. Emotional conflicts caused by feelings of anger, disbelief, not sympathy, fear, rejection and disagreement between individuals (Robbins, 2003).

Symptoms conflict substantive and emotional it often occurs between the legislature and the executive on the budget process, so often the effect on the work environment that is conflict within the individual itself, which raised the arrogance and attitude that over load or excessive in response to a decision, so it takes understanding of interpersonal conflict that is focused on resolving the conflict so as not to give birth to the ongoing conflict. According to Robbins (2003) conflict can influence positively or negatively, and always in life. Therefore, the conflict should not have to be eliminated. The problem is how it could be in conflict management in a way that does not cause social disintegration. Conflict management means to it that the conflict was at optimal levels. If the conflict becomes too large and leads to a bad outcome, then the conflict should be resolved. On the other hand, if the conflict is at a level that is too low, then the conflict should be raised. Conflict management strategy refers to an activity that is intended to manage the conflict from the planning, evaluation, and solution / settlement of a conflict that it becomes something positive for a change and goal achievement.

Addressing conflicts of interest between the legislature and the executive in the budget process are relevant to the theory of conflict behavior of two dimensions of Robbins (2008) that the conduct of the conflict can be dealt with through action cooperativeness' is a certain level where one party seeks to satisfy the interests of the other party and firmness that is to some degree where a party seeks to meet its own interests. It identified five dimensions of conflict behavior which competitive (assertive and uncooperative), collaborative (assertive and cooperative), avoiding (unassertive and uncooperative), accommodating (cooperative and indecisive) and compromising (the middle in terms of firmness and cooperative). Problem behaviors agency conflicts raised in this study relates to the preparation of policies and Determination of Regional Budget (APBD) Government Fiscal Year 2015 are implemented by the executive (local government) and the legislature (DPRD).

The conflict between the legislatures is certainly not out of the conflict episode. There are four approaches used in conflict: (1) approaches conflict, i.e. situations where one must choose one among several alternatives that are just as good; (2) avoidances conflict, namely the circumstances in which a person forced to choose one among several alternative destinations which are just as bad; (3) approach - avoidance conflict, a situation where a person motivated by a strong desire to achieve one goal, but on the other hand simultaneously often hindered from that purpose by aspects unfavorable cannot be separated from the process of achieving the goal itself; and (4) multiple approach-avoidance conflict, which is a situation where someone forced confronted with cases of multiple combinations of approach-avoidance conflict (Tosi et al.,2006).

Approach episodes of this conflict, the various issues related to the potential conflict occurs because of the behavior and actions of each of the different agencies in actualizing the policy formulation of Public Policy budget (KUA), the preparation of Priorities and Budget Ceiling While (PPAS) and Preparation of Draft Budget income and Expenditure (RAPBD), which refers to Government Regulation Number 58/2005 on Guidelines for regional Financial Management. This policy is the basis for local governments and the Regional Representatives Council (DPRD) to realize the implementation of financial management accountable and transparent. The Musrenbang budgeting originally started in the village, district and county. Musrenbang is the basis for the preparation of Local Government Work Plan (RKPD) in one fiscal year. Local Government Work Plan (RKPD) is the basis for the drafting of the Budget and Expenditure (RAPBD).

Musrenbang is also a public aspirations net more often known as netting romance. Nets romance is a container used to screen a variety of Parliament or the public interests of their constituents. Various interests are accommodated and discussed through the agency budget. The Musrenbang implemented by executive referred to in the discussion of budget by budget team. Romance nets carried out by Parliament and then synchronized with Musrenbang. This could potentially occur in synchronization conflicts of interest that led to delays in the preparation and approval of the budget.

Conflict management is a way that individuals use in controlling, directing, and resolve conflicts, in this case is interpersonal conflict. Through various methods of resolution conflict, as follows: First, the method of use of force. People often use the power and authority so that conflicts can be mitigated or extinguished. 
Second, the parties to the conflict should be mutual understanding of the conflict with the language of love, to break and restore relationships that lead to peace. Third, that is, providing an opportunity for each party to express opinions and give his opinion faith in the truth that can be accepted by both parties.

The strategy is seen as more effective in conflict management include: (1) peaceful coexistence, which control the conflict by not interfere with each other and hurt each other, with set rules that refer to peace and to be applied strictly and consistently; (2) with the mediation (the intercession). If settlement of the conflict deadlocked, each party can appoint a third party to be intermediaries that act honestly and fairly and impartially. On the other hand, are seen as the most effective strategy, among others: (1) the purpose major ally, by involving the parties to the conflict towards the larger goals and complex. For example, by way of building a more robust national consciousness; (2) bargaining integrative, i.e. by bringing the parties to the conflict, to concentrate more on broad interest, and not only the range of narrow interests, for instance the interests of the individual, group, class or race specific (Riggs, 2008).

Conflict and integration runs as a cycle in the community. Controlled conflict will result integration. Instead, an imperfect integration can create conflicts. The institution in question is expected to function effectively, which meets at least four things: (1) must be able to take decisions autonomously, without interference from other agencies; (2) The institution should be monopolistic, in the sense that institutions are functioning so; (3) The institution should be able to bind the interests of the parties to the conflict; and (4) the institution must be democratic. Without these four, the conflict between some social forces will appear below the surface, which in turn will explode again in the form of violence. Control by means of mediation, with the intention that the parties to the conflict agree to appoint a third party who will provide advice, in association with the best solution to the conflicts they experienced. Control of the conflict by means of arbitration, it is intended that the conflicting parties agree to accept a third party, which will serve to provide decision-making, in order to resolve the existing. In contrast to mediation, a way of arbitration requires the parties to the conflict to accept the decisions taken by the referee.

The pattern of conflict resolution can also be done by using strategies such as the following: (1) use the competition in the resolution of the conflict, when quick and decisive action is vital, on important issues, in which the unpopular measures need to be implemented; (2) use collaboration to find integrative problem solving when both devices interests are too important to be compromised; (3) use avoidance when there was an issue (issue) is trivial, or no issue (issue) is more important urgency; if you see no opportunity for satisfying the interests you; (4) use of accommodation if it is known we are wrong and to allow the establishment of better heard, to learn, and to show fairness; and (5) use of compromise when an important goal, but it does not deserve the effort approaches a more assertive with the possibility of interference.

The ability to confront and deal with conflict is one key to success in an organization. Whenever expect a change, there is definitely potential for conflict. For that every individual should be able to handle situations in which a conflict between self or one or more other members, but also the time needed to resolve the conflict. Conflict is a divergence of the possibility of two or more directions objectives and actions are not only inevitable but also as something to be reckoned with in life. Conflict has two components, namely the substance and emotional, located somewhere along the two images between the conflicts on the one hand and on the other side of personality clashes.

Approach to conflict resolution categorized in two dimensions; cooperation and firm that uses five kinds of approaches: (1) avoidance regarding indifference of both groups. This situation illustrates the withdrawal of interest or ignoring the interests of other groups; (2) property, namely conflict resolution described the competition mirror images are on the whole settlement on the other side without any attempt to fight for own ends. The process is similar to the tactics of peace; (3) which is a compromise between the approach of the dominance of groups and peace groups. One side gives and the other receives something. Both groups minded moderate, not exhaustive, but is satisfying; (4) competition that conflict resolution that defined the beat or the expense of others. Completion of the form of competition known as win-lose orientation; and (5) collaboration namely establishment of conflict resolution that is satisfactory to both parties. This effort is the approach to problem solving which requires the integration of both sides.

\section{CONCLUSION}

The results of this research led to several findings, namely; (1) there is a conflict and debate between the executive and the legislature that cause conflict behavior in determining the theme of development, development priorities, plans macroeconomic targets and strategies to achieve revenue, financing and expenditures at the stage of preparation of KUA Government; (2) there is a conflict in the determination of the plan PAD, determination of financing, income and expenditure, the determination of regional government affairs, prioritization of programs and activities and the determination of employee expenses, interest, grants, social assistance and expenditure unexpected cause behavioral conflicts between the executive and PPAS legislature at the time of the determination of the Government; (3) there is a debate that lead to behavioral 
conflict between the executive and legislature in the Plenary Session, Joint Meeting, RAPBD Evaluation Meeting, the Plenary Session of Approval and Evaluation Meeting of Governors discussed the draft budget of the Government; and (4) the right model to use in resolving the conflict between the executive and the legislature in the budget process, namely Model Settling Conflicts can neutralize, minimize, optimize and prevent the ongoing conflict.

\section{REFERENCES}

[1] Kusnadi, 2003. Theory and Conflict Management. Tadora, Malang.

[2] Luthans F, 2005. Organizational Behavior, Mc Graw Hill, Singapore.

[3] Pruitt, Dean G and Z Jeffrey Rubin, 2004. Theory of Social Conflict. Reader Student, Yogyakarta. Translation: Sulystio.

[4] Rigg, s Wankel, 2008. The Organization in Action. Brooks / Cole Publishing Company, Pacific Grove, California.

[5] Robbins, Stephen P. 2003. Organizational Behavior, Prentice Hall,

[6] Robbins, Stephen P. 2008. Organization Theory: Structure, Design and Application. Interpretation: Jusuf Udaya, Lic., Ec. Publisher Arcan, Jakarta.

[7] Robbins, Stephen P. 2010. Organizational Behavior. Interpretation: Jusuf Udaya, Lic., Ec. Publisher Arcan, Jakarta.

[8] Tosi, Henry L. John R. Rizzo, and Stephen J. Carrol. 2006. Managing Organizational Behaviour, Ballinger Publishing Company, Cambridge, Massachusetts.

[9] Tunner, Stodgil, 2000. The Basic Science of Organization. Published by John Wiley and Sons, New York

[10] Tyson, Shaun and Jackson, Tony, 2001. The Essence of Organizational Behavior: Organizational Behavior. First Edition, Moulds Second, Interpreting Deddy Jacobus and Dwi Prabantini, Andi, Yogyakarta.

\section{Regulation Legislation:}

[11] Indonesian Government Regulation No. 58 Year 2005 on Regional Financial Management Guidelines.

[12] Law of the Republic of Indonesia Number 1 Year 2004 concerning State Treasury.

[13] Law of the Republic of Indonesia Number 17 Year 2003 on State Finance.

[14] Law of the Republic of Indonesia Number 25 Year 2004 on National Development Planning System.

[15] Law of the Republic of Indonesia Number 33 of 2004 on Financial Balance between Central and Local Government. 